\title{
PENGARUH KUALITAS DAN PROMOSI TERHADAP JUMLAH MAHASISWA INSTITUT SAINS DAN TEKNOLOGI AL-KAMAL (ISTA)
}

\author{
Ahmad Sofan Ansor ${ }^{1}$ Djoko Subali ${ }^{2}$ \\ ${ }^{1,2}$ Dosen Politeknik PGRI Banten \\ email:sofanansor65@gmail.com \\ email:agus.surajim@gmail.com
}

\begin{abstract}
The sucsess of an education institution is to create a quality environment and promotional activities that show the sucsess of the campus to the community. Research result indicate that college promotion and quality together have influenced college ISTA student acquirement Amount this matter is proved from result analysis got that value $t_{\text {hitung }}(3.128)>t_{\text {table }}(1.996)$ with the freedom degree (df) 2 dan 67 at alpha ( $\alpha$ ) 0.05 and 0.853, so that the hypothesis which take is Ho refused and $H_{1}$ accepted. College Promotion also have influence which significant to Acquirement Sum up College ISTA that is thitung (2.720) > ttable (1.996) so that its decision refuse Ho. and accept $H_{1}$. Coefficient Determinant $\left(R^{2}\right)$ of equal to $78.0 \%$, and $22,0 \%$ other influenching factors were not analysis.
\end{abstract}

Keywords: quality, promotion, student, college

\begin{abstract}
ABSTRAK
Kesuksesan sebuah institusi pendidikan adalah menciptakan lingkungan pendidikan yang berkualitas dari berbagai segi dan kegiatan promosi perguruan tinggi yang menunjukan keberhasilan kepada masyarakat Hasil penelitian menunjukan bahwa promosi dan kualitas perguruan tinggi secara bersama-sama berpengaruh terhadap perolehan mahasiswa. Hal ini dibuktikan dari hasil analisis didapatkan bahwa nilai thitung (3.128)>rtabel (1.996) dengan derajat kebebasan (df)2 dan 67 pada alpha ( $\alpha$ ) 0.05 dan 0.853, sehingga hipotesis yang diambil adalah $\mathrm{Ho}$ ditolak dan $\mathrm{HI}$ diterima. Promosi juga memiliki pengaruh yang signifikan terhadap jumlah perolehan mahasiswa yaitu memiliki nilai thitung (2.720)>ttabel (1.996), sehingga menolak Ho dan menerima H. Kualitas dan promosi memiliki pengaruh secara bersama-sama dengan hasil uji fhitung 13.443>ftabel 3.14 dengan Rhitung $0.446>$ Rtabel 0.396 sehingga hipotesis menolak Ho dan menerima $H^{I}$. Koefesien determinan $\left(R^{2}\right)$ sebesar $78.0 \%$ dan $22.0 \%$ faktor berpengaruh lain tidak dianalisis.
\end{abstract}

Kata kunci: kualitas, promosi, mahasiswa, perguruan tinggi

\section{PENDAHULUAN}

Pembiayaan Perguruan Tinggi Swasta (PTS) saat ini sangat mahal, karena tuntutan akreditasi program studi dan lembaga pendidikan mengharuskan memenuhi persyaratan tersebut. Kondisi persaingan bisnis industri perguruan tinggi yang sangat ketat, perlu adanya informasi yang cepat, promosi yang tepat dan gencar serta adanya metode analisis yang akurat. Terlebih lagi pada kondisi pasar yang terpilah-pilah, dimana pasar massal telah terpecah dan berubah menjadi pasar kecil yang menuntut berbagai spesialisasi model, warna, jenis produk, ukuran, kualitas dan sebagainya. Untuk itu sangat diperlukan pemahaman yang 
sangat kongkret dan rinci mengenai signal kondisi pasar, perilaku masyarakat sebagai konsumen maupun kebiasaan-kebiasaan lainnya.

Jaminan mutu atau kualitas bertujuan untuk mencegah terjadinya kesalahan sejak awal produksi. Jaminan mutu didesain sedemikian rupa untuk menjamin bahwa proses produksi menghasilkan produk yang memenuhi spesifikasi yang telah ditetapkan sebelumnya. Jaminan mutu adalah sebuah cara memproduksi produk yang bebas dari cacat dan kesalahan. Istilah Philip B. Crosby menciptakan produk tanpa kesalahan, tanpa cacat (zero defects). Jaminan mutu lebih menekankan pada tanggungjawab tenaga kerja dibandingkan inspeksi kontrol mutu. Mutu barang atau jasa yang baik dijamin oleh system yang dikenal dengan system penjaminan mutu. Standar-standar mutu diatur oleh prosedur-prosedur yang ada dalam system penjaminan mutu. (Edward Salis 2008:58).

Kualitas pendidikan Perguruan Tinggi berdasar penetapan akreditasi yang ditentukan oleh Badan Akreditasi Nasional PT dengan menilai kualitas PT berdasar peringkat. Untuk itu PT harus memenuhi tuntutan akreditasi berdasar kebutuhan masyarakat setiap program studinya memiliki jaminan kualitas (quality assurance), pengendalian kualitas (quality control) dan perbaikan kualitas (quality improvement). PT tidak sebatas memiliki kemampuan untuk menghasilkan lulusan yang diukur secara akademik, melainkan keseluruhan program lulusannya harus mampu membuktikan prestasi dan dapat diterima diberbagai bidang pekerjaan yang sesuai dengan bidang ilmunya. Evaluasi produk PT ditentukan oleh pengakuan masyarakat, pemerintah dan dunia usaha pengguna lulusan Perguruan Tinggi.

Evaluasi atas kualitas pendidikan perlu juga dilakukan kepada mahasiswa pengguna layanan PT tesebut. Evaluasi kualitas jasa dapat dilakukan dengan menggunakan dimensi dari reability (keandalan), responsiveness (daya tanggap), assurance (jaminan), emphaty and tangibles (bukti fisik), (Kotler, 1997). Evaluasi PT dilakukan untuk mengetahui apa yang sebenarnya diharapkan oleh mahasiswa dan apa yang selama ini dipersepsikan oleh mahasiswa yang terkait dengan kualitas jasa yang diterimanya. Baik dan buruknya kualitas pendidikan tergantung dari lembaga pendidikan untuk memenuhi kebutuhan dan harapan mahasiswanya sebagai pengguna dan pemakai jasa pendidikan.

Hakekat penjualan produk dalam memperoleh jumlah mahasiswa adalah merupakan suatu hal yang harus dilakukan sebuah perguruan tinggi, sehingga sebuah perguruan tinggi akan tetap langgeng apabila dalam penjualan produk seperti perolehan jumlah mahasiswa dapat 
meningkat. Menurut Ulrich, (2001) ada tiga fungsi yang selalu menyertai pengembangan produk yaitu; (1) pemasaran, (2) perancangan, dan (3) sistem produksi. Sistem produksi pada perguruan tinggi ditentukan oleh dosen, staf, peralatan, fasilitas, energi, buku-buku dan pengetahuan. Hasil produk perguruan tinggi seperti mahasiswa terdidik, riset dan pengabdian masyarakat.

Kampus Institut Sains dan Teknologi Al-Kamal (ISTA) memiliki program perkuliahan pada delapan program studi yaitu teknik kimia, teknik industri, teknik mesin, teknik sipil dan farmasi. Keunggulan ISTA yaitu banyak memiliki guru besar (Profesor), akademisi mantan pejabat, dosen professional dan praktisi. Saat ini (tahun 2020) rektor dijabat oleh Dr Dede Rukmayadi, MSi, yang rector sebelumnya dijabat oleh alm Prof Dr Haryanto Dhanutirto, DEA mantan menteri perhubungan, dan alm Prof Dr Ir HM Satari, mantan rektor IPB. Semua program studi teknik dan sains di lingkungan ISTA sudah terakreditasi sehingga ISTA berwenang menyelenggarakan proses belajar mengajar secara mandiri, meliputi penerimaan mahasiswa, kegiatan kuliah, evaluasi belajar (ujian) dan menerbitkan ijasah.

Kesuksesan perguruan tinggi ditentukan sejauhmana lingkungan pendidikan yang berkualitas diciptakan. Burge dan Tannock dalam Rowley mengartikan mutu pendidikan sebagai the success with which an institution provides educational environments which enable students effectively to achieve worthwhile learning goals including appropriate academic standards (Rowley, Jennifer. 1995:24). Masalah kualitas dalam era sekarang ini merupakan masalah berkaitan dengan hidup dan matinya suatu organisasi terutama organisasi bisnis, oleh karena itu tidaklah berlebihan jika Rene T Domingo menulis buku berjudul Quality means Survival (1997), artinya kualitas bermakna kehidupan. Untuk itu upaya untuk menjadikan organisasi bertahan, masalah kualitas harus menjadi perhatian termasuk dalam bidang pendidikan, dan oleh karenanya maka penjaminan kualitas menjadi suatu keharusan untuk diterapkan dalam suatu organisasi dalam kerangka Manajemen Kualitas Terpadu (Total Quality Management). Kualitas Jasa pendidikan ditentukan oleh lima dasar mutu yaitu keandalan (reliabity), daya tanggap (responsiveness), Jaminan kepastian (assurance), Sikap peduli (emphaty) dan bukti fisik (tangibles). Kualitas suatu product tergantung kesesuain pada pemenuhan kepuasan pemakai, fitness for use.

Pemasaran adalah suatu proses sosial dan manajerial yang didalamnya individu dan kelompok mendapatkan apa yang mereka butuhkan dan inginkan dengan menciptakan, 
menawarkan dan mempertukarkan produk yang bernilai dengan pihak lain (Kotler, 1997). Berdasar definisi tsb konsep pemasaran bersandar pada kebutuhan (needs), keinginan (wants), permintaan (demands), produk (barang, jasa dan gagasan), nilai, biaya, kepuasan, pertukaran, dan transaksi, hubungan, dan jaringan, pasar, serta pemasar dan prospek. Kunci konsep pemasaran dalam mencapai tujuan organisasi adalah menjadi lebih efektif daripada para pesaing dalam memadukan kegiatan pemasaran guna menetapkan dan memuaskan kebutuhan dan keinginan pasar sasaran. Empat pilar konsep pemasaran yaitu pasar sasaran, kebutuhan pelanggan, pemasaran terpadu dan profitabilitas.

Kunci sukses usaha menurut Mc Kinsey adalah 7S yaitu Strategy, Structure, System, Style, Staff, Skill and Shared value. Sedang esensi pemasaran strategis yaitu rumusan pembagian, penentuan sasaran dan penentuan posisi atau biasa dikenal dengan Segmentation, Targeting and Positioning (STP). Bauran pemasaran adalah perangkat alat pemasaran yang digunakan untuk mencapai tujuan pemasaran. Menurut McCarty memperkenalkan 4P yaitu Product, Price, Place and Promotion. 4P merupakan pandangan penjual terhadap alat pemasaran untuk mempengaruhi pembeli. Robert Lauterbon menyarankan tanggapan terhadap $4 \mathrm{P}$ yaitu 4C, Costumer needs and wants, Cost to customer, Convenience (kemudahan memperoleh), and Communication.

Berdasar uraian diatas, kualitas suatu lembaga pendidikan dan promosi sangat penting dimiliki oleh organisasi apapun, untuk itu peneliti mengganggap penting sejauh mana pengaruh kedua variable bebas berpengaruh langsung pada peroleh jumlah mahasiswa (variable terikat) pada Institut Sains dan Teknologi Al-Kamal.

\section{METODE PENELITIAN}

Penelitian deskriptif analitis memberikan gambaran yang lebih mendalam tentang gejala-gejala sosial tertentu atau aspek kehidupan tertentu pada masyarakat (objek) yang diteliti. Pendekatan tersebut dapat mengungkapkan secara nyata kaitan antara berbagai gejala sosial, suatu hal yang tak dapat dicapai oleh penelitian yang bersifat menerangkan (Singarimbun 2009:78). Menurut Riduan (2007) teknik analisis yang digunakan yaitu menggunakan teknik analisis jalur (path analisis). Analisa jalur merupakan teknik penelitian kuantitatif yang digunakan untuk menganalisis pola hubungan antar variabel dengan tujuan untuk mengetahui pengaruh langsung maupun 
tidak langsung seperangkat variabel bebas (eksogen) dengan variabel terikat (endogen).

Penelitian ini mengkaji hubungan 3 variabel, yang terdiri dari 2 variabel bebas dan 1 variabel terikat. variabel bebas yaitu kualitas $\left(\mathrm{X}_{1}\right)$ dan promosi $\left(\mathrm{X}_{2}\right)$, sedangkan variabel terikat adalah jumlah mahasiswa Institut Sains dan Teknologi Al-Kamal Jakarta (Y).

Populasi target penelitian ini adalah seluruh jumah mahasiswa baru dan pengambilan sampel dilakukan secara teknik Pourposive Random Sampling yaitu teknik pengambilan sampel di mana dari anggota populasi ditunjuk langsung dan ditentukan jumlahnya untuk dijadikan sampel penelitian dengan pengambilan secara acak. Karena keterbatasan waktu dan biaya maka besarnya sampel yang diambil pada penelitian ini yaitu sebanyak 67 mahasiswa dari populasi 160 mahasiswa baru yang menjadi objek penelitian dengan asumsi bahwa sampel sudah cukup terwakili dan data cukup heterogen, sehingga dengan pengambilan sampel sebanyak ini dapat dianggap telah memenuhi persyaratan dan mewakili populasi.

Teknik pengumpulan data hanya penelusuran data kampus (dokumentasi) dan pengajuan daftar isian kuisioner yang dilakukan peneliti dan akan dianalisis lebih lanjut. Alat untuk mengumpulkan data dilakukan dengan cara memberikan pernyataan secara tertulis kepada responden, di mana pada setiap jawaban dari pernyataan yang diajukan telah ditentukan alternatif jawabannya. Alternatif jawaban disusun dalam 5 alternatif dan responden dapat memilih salah satu jawaban yang dianggap benar. Setiap jawaban diberikan bobot nilai seperti berikut :

- Sangat Setuju (SS) dengan bobot nilai 5,

- Setuju (S) dengan bobot nilai 4,

- Tidak Penting (TP) dengan bobot nilai 3,

- Tidak Setuju (TS) dengan bobot nilai 2, dan

- Sangat Tidak Setuju (STS) dengan bobot nilai 1.

Pemberian bobot ini sangat diperlukan sebagai langkah awal untuk mendapatkan data secara kuantitatif sehingga dapat memudahkan dalam melakukan perhitungan secara statistik.

\section{PEMBAHASAN}


Perguruan Tinggi Institut Sains dan Teknologi Al-Kamal (ISTA) yang mempunyai akreditasi B dari Badan Akreditasi Nasional Perguruan Tinggi dan alamat Institut Sains dan Teknologi Al-Kamal di jalan raya Al-Kamal nomor 2 Kebon Jeruk Jakarta Barat. Memiliki program pendidikan dengan delapan program studi yang berada dalam tiga Fakultas. Program studi yaitu Prodi Teknik Mesin, Teknik Sipil, Teknik Kimia, Teknik Industri, Farmasi, Teknik Informatika, Sistem Informasi dan Desain Komunikasi Visual. Fasilitas kampus yang megah, berdiri bangunan kampus tiga lantai dan memiliki ruang kelas yang cukup, fasilitas laboratorium, lapangan olah raga, gedung pertemuan dan musola. Sedangkan jumlah mahasiswa sampai saat ini berjumlah \pm 675 orang dari semua program studi yang ada dan diajar oleh \pm 48 staf pengajar dari berbagai disiplin ilmu yang jenjang pendidikannya $85 \%$ S2, $15 \% \mathrm{~S} 3$.

Berdasarkan hasil pengumpulan data baik primer maupun sekunder, diperoleh gambaran hasil penelitian. Data diolah berdasarkan data yang telah terkumpulkan melalui alat kuisioner pengumpul data. Sesuai jumlah responden yang ditetapkan sebelumnya, kemudian melakkukan penyebaran kuisioner kepada responden dengan jumlah angket yang disebarkan kepada responden sebanyak 70 eksemplar dan dikembalikan secara keseluruhan sebanyak 67 eksemplar, karena tiga (3) eksemplar lainnya rusak atau jawaban tidak sesuai dengan kriteria yang ditentukan.

Setelah data angket (kuisioner) dipilah-pilih, ternyata secara keseluruhan memenuhi syarat dan layak untuk dianalisis. Kemudian dengan menggunakan alat bantu komputer program SPSS 22.0 for Windows, data analisis dan diinterpretasikan guna memecahkan permasalahan yang telah dirumuskan sebelumnya.

Analisis variable kualitas pendidikan terhadap perolehan mahasiswa berpengaruh secara positif dan signifikan. Hal ini ditunjukan oleh hasil thitung untuk b1 diperoleh sebesar 3.128 sedangkan $\mathrm{t}$ table dengan derajat kebebasan df 67 dan alfa 0.05 dan 0.853 adalah sebesar 1.996, dengan demikian thitung (3.128)> ttabel (1.196). Hal ini menunjukan bahwa Kualitas pendidkan dapat mempengaruhi perolehan mahasiswa. Kualitas yang diharapkan dari mahasiswa yaitu memiliki kampus yang memiliki legalitas mutu seperti akreditasi perguruan tinggi dan akreditasi setiap program studi dan pelayanan pendidikan yang berkualitas.

Dengan bantuan Histogram terlihat penumpukan batang yang lebih banyak terjadi pada kelas interval yang keenam, ketujuh kesembilan, kesebelas, kedua belas, ke tiga belas dan 
interval ke empat belas. Adapun jumlah proporsinya mencapai 48,2\% dari keseluruhan responden dan termasuk di dalam kelompok nilai di bawah rata-rata sampai diatas rata-rata. Jika dirinci lebih lanjut ternyata sebanyak 32,1\% responden termasuk di dalam kelompok di bawah rata-rata dan selebihnya $67,9 \%$ termasuk di dalam kelompok rata-rata dan di atas ratarata. Berdasarkan batas-batas data yang telah terkumpulkan tersebut, maka dapat dikemukakan bahwa Kualitas Pendidikan pada Perguruan Tinggi ISTA tergolong dalam kategori relatif belum memuaskan.

Perlu usaha perguruan tinggi untuk meningkatkan akreditasi program studi yang ada dengan penambahan fasilitas penunjang kualitas pendidikan sehingga memenuhi standar mutu pendidikan. Standar mutu mendidikan meliputi pelaksananaan dan pengembangan kurikulum yang disesuaikan dengan kebutuhan dunia industri (user) dan ketrampilan. Standar pelaksanaan pembelajaran yang nyaman dan berjalan disiplin sesuai dengan target capaian pembelajaran. Standar penilaian, kelulusan, tenaga pendidik dan kependidikan, serta pemenuhan sarana prasarana.

Analisis Variabel Promosi dalam meningkatkan Perolehan Jumlah Mahasiswa Perguruan Tinggi ISTA berpengaruh besar dan signifikan. Hal ini ditunjukan oleh oleh hasil thitung 2.720 sedangkan ttabel 1.996 dengan derajat kebebasan df 2, alpha 0.05 dan 0.853, dengan demikian thitung> ttabel 1.996. Hal ini menunjukan pengaruh yang besar akan promosi terhadap perolehan mahasiwa. Promosi yang diharapkan berupa informasi yang mudah diakses dan diketahui oleh calon mahasiswa dan kemudahan mahasiswa untuk berkomunikasi dengan bagian penerimaan mahasiswa baru.

Terlihat pada Histogram bahwa penumpukan batang yang lebih banyak terjadi pada kelas interval yang keenam, kedelapan, kesembilan dan interval ke duabelas. Adapun jumlah proporsinya mencapai $38,8 \%$ dari keseluruhan responden dan termasuk di dalam kelompok nilai di bawah rata-rata sampai di atas rata-rata. Jika dirinci lebih lanjut ternyata sebanyak 47,4\% responden termasuk di dalam kelompok di bawah rata-rata dan selebihnya 52,6\% termasuk di dalam kelompok rata-rata dan di atas rata-rata. Berdasarkan batas-batas data yang telah terkumpulkan tersebut, maka dapat dikemukakan bahwa Promosi Perguruan Tinggi ISTA tergolong dalam kategori relatif belum memuaskan.

Selanjutnya mengenai distribusi frekuensi skor jawaban responden tentang Variabel Perolehan Jumlah Mahasiswa pada Perguruan Tinggi Swasta ISTA kampus Serang di Banten, 
seperti tampak dalam tabel frekuensi. Untuk menggambarkan frekuensi hasil data penelitian variabel Perolehan Jumlah Mahasiswa (Y), dapat disajikan dalam bentuk distribusi frekuensi.

Berdasarkan distribusi frekuensi terlihat bahwa sebanyak $22,4 \%$ responden memiliki nilai skor dalam kelompok rata-rata dan 32\% responden memiliki skor nilai dalam kelompok di atas rata-rata. Sedangkan sisanya sebanyak 45,6 \% responden memiliki skor nilai dalam kelompok di bawah rata-rata. Apabila dirinci lebih lanjut ternyata sebanyak 45,6\% responden termasuk di dalam kelompok di bawah rata-rata dan selebihnya 54,4\% termasuk di dalam kelompok rata-rata dan di atas rata-rata. Dengan demikian berdasarkan batas-batas data yang telah terkumpulkan tersebut, maka dapat dikemukakan bahwa Perolehan Jumlah Mahasiswa Perguruan Tinggi ISTA tergolong dalam kategori relatif belum maksimal.

Perolehan jumlah mahasiswa belum mencapai jumlah yang diharapkan, hal ini disebakan belum maksimal mesin penerimaan mahasiswa baru bekerja. Banyak factor yang menjadi kendala untuk dapat memperoleh jumlah mahasiswa yang diharapkan, minimal setiap prodi mendapat dua kelas baru.

Analisis dalam penelitian ini dapat dilihat dari output hasil print out computer (terlampir), baik pada bagian output berupa chart maupun angka. Pada bagian output berupa chart, mengenai persyaratan normalitas, bahwa sebaran data pada chart Normal Probability Plot tersebar disekeliling garis lurus, sehingga dapat dikatakan bahwa persyaratan normalitas bisa terpenuhi.

Untuk kelayakan model regresi (model fit), bahwa dari chart yang menggambarkan hubungan antara nilai yang diprediksi dengan Studentized Delete Residual-nya, terlihat sebaran data ada disekitar titik nol serta tidak tampak adanya suatu pola tertentu pada sebaran data tersebut, sehingga model regresi memenuhi syarat untuk memprediksi Perolehan Jumlah Mahasiswa pada Perguruan Tinggi Swasta ISTA.

Kemudian untuk model fit tiap data, bahwa dari gambar yang menampakkan pengaruh antara Variabel Perolehan Jumlah Mahasiswa pada Perguruan Tinggi Swasta ISTA dengan nilai prediksinya, terlihat sebaran datanya membentuk arah yang dipersyaratkan, yaitu sebaran data akan berada mulai dari kiri bawah lurus ke kanan atas. Karena itu bisa dikatakan bahwa model regresi sudah layak digunakan.

Selanjutnya, pada bagian output berupa 2 (dua) buah chart berikutnya (Partial Regression Plot), untuk menganalisis pengaruh setiap variabel bebas dengan variabel terikat, terlihat 
bahwa sebaran data juga membentuk arah yang di persyaratkan, yaitu membentuk arah ke kanan atas dan jika ditarik garis lurus akan didapat slope yang positif. Hal ini sesuai dengan koefisien regresi (yang adalah nilai slope), baik Kualitas Pendidikan maupun Promosi Perguruan Tinggi yang positif. Pada output bagian angka, dalam penelitian ini juga menunjukkan tidak terjadi adanya autokorelasi.

Dengan demikian dalam penelitian ini dapat dikatakan bahwa persyaratan analisis terpenuhi, sehingga dapat dilakukan uji statistik lebih lanjut. Uji Hipotesis penelitian ini terdapat 3 (tiga) buah hipotesis yang diajukan atau diuji, sebagai berikut:

1. Ho : b1 = b2 = 0 ; tidak terdapat pengaruh Kualitas Pendidikan dan Promosi secara bersama-sama terhadap Perolehan Jumlah Mahasiswa.

Hi : Salah satu atau kedua bi $\neq 0$ : terdapat pengaruh Kualitas Pendidikan dan Promosi secara bersama-sama terhadap Perolehan Jumlah Mahasiswa.

Jika $t_{\text {hitung }}>\mathrm{t}_{\text {tabel}}$, maka Ho ditolak dan Hi diterima.

2. Ho : b1 =0 ; tidak terdapat pengaruh Kualitas Pendidikan terhadap Perolehan Jumlah mahasiswa.

Hi : $\mathrm{b} 1 \neq 0$; terdapat pengaruh Kualitas Pendidikan terhadap Perolehan Jumlah Mahasiswa. Jika $\mathrm{t}_{\text {hitung }}>\mathrm{t}_{\text {tabel}}$, maka Ho ditolak dan Hi diterima.

3. Ho :b2 = 0 ; tidak terdapat pengaruh Promosi terhadap Perolehan Jumlah Mahasiswa. Jika $\mathrm{t}_{\text {hitung }}>\mathrm{t}_{\text {tabel}}$, maka Ho ditolak dan Hi diterima.

Analisis pengaruh variabel Kualitas Pendidikan dan Promosi, baik secara bersama-sama maupun secara sendiri-sendiri terhadap Perolehan Jumlah Mahasiswa pada Perguruan Tinggi ISTA memperlihatkan hasil yang signifikan.

Hal ini menujukkan bahwa kedua variabel bebas, yaitu Kualitas Pendidikan dan Promosi baik secara bersama-sama maupun secara sendiri-sendiri dapat meningkatkan Perolehan Jumlah Mahasiswa pada Perguruan Tinggi ISTA. Dengan demikian pengaruh kedua variabel bebas tersebut terhadap peningkatan Perolehan Jumlah Mahasiswa pada Perguruan Tinggi ISTA sangat berarti. Jika pengaruh variabel tersebut dibahas lebih lanjut, maka hasilnya dapat digambarkan sebagaimana uraian berikut ini.

Pengaruh Kualitas Pendidikan dan Promosi secara bersama-sama terhadap Perolehan Jumlah Mahasiswa Perguruan Tinggi ISTA. 
Sebagaimana diuraikan pada bagian uji hipotesis, bahwa variabel Kualitas Pendidikan dan Promosi secara bersama-sama berpengaruh positif terhadap Perolehan Jumlah Mahasiswa pada Perguruan Tinggi ISTA. Hal ini ditunjukkan dari nilai $\mathrm{F}$ hitung yang diperoleh sebesar 13.443, sementara harga kritis nilai $F_{\text {tabel }}$ dengan derajat bebas pembilang 2 dan penyebut 67 pada $\alpha$ ( 0,05 dan 0.853$)$ sebesar 3.14 sehingga terbukti bahwa $F$ hitung $(13.443)>F_{\text {tabel }}($ 3.14 ). Dengan demikian bahwa variabel Kualitas Pendidikan dan Promosi secara bersamasama dapat meningkatkan Perolehan Jumlah Mahasiswa pada Perguruan Tinggi ISTA.

Hasil penelitian ini juga menggambarkan bahwa sebanyak $78 \%$ keragaman variabel Perolehan Jumlah Mahasiswa pada Perguruan Tinggi ISTA disebabkan oleh perbedaan keragaman variabel Kualitas Pendidikan dan Promosi, sisanya sebanyak 22\% disebabkan oleh faktor lain yang tidak diteliti. Dengan demikian pengaruh kedua faktor tersebut terhadap peningkatan Perolehan Jumlah Mahasiswa pada Perguruan Tinggi ISTA sangat berarti.

\section{KESIMPULAN}

1. Faktor kualitas pendidikan dan promosi perguruan tinggi secara bersama-sama mempunyai pengaruh yang positif terhadap peningkatan jumlah perolehan mahasiswa pada perguruan tinggi ISTA. Hal ini diperoleh dari hasil pengolahan data dengan nilai $\mathrm{F}_{\text {hitung }}$ sebesar, 13.443 sedangkan besarnya $F_{\text {tabel }}$ dengan derajat bebas (df) 2 dan 67 pada alfa ( $\alpha$ ) 0,05 sebesar 3,14. Dengan demikian nilai $F_{\text {hitung }}(13.443)>F_{\text {tabel }}(3,14)$, sehingga hipotesis yang diambil harus menolak Ho dan harus menerima $\mathrm{H}_{1}$.

2. Kualitas Pendidikan mempunyai pengaruh yang positif terhadap peningkatan Perolehan Jumlah Mahasiswa pada perguruan tinggi ISTA. Hal ini berdasarkan hasil pengolahan data dengan bantuan komputer SPSS diperoleh nilai thitung sebesar 3.128, sedangkan besarnya tabel dengan derajat bebas (df) 2 dan 67 pada $\alpha$ (0,05 dan 0.853) sebesar 1,996. Dengan demikian nilai thitung (3.128) > tabel, $(1,996)$, sehingga hipotesis yang diambil Ho ditolak dan $\mathrm{H}_{1}$ diterima.

3. Promosi mempunyai pengaruh yang positif terhadap peningkatan jumlah perolehan mahasiswa. Hal ini berdasarkan hasil pengolahan data diperoleh nilai thitung sebesar 2.720, sedangkan besarnya $t_{\text {tabel }}$ dengan derajat bebas (df) 67 pada alfa $(\alpha) 0,05$ sebesar 1,996: Dengan demikian nilai $t_{\text {hitung }}$ (2.720) $>\mathrm{t}_{\text {tabel }}(1,996)$, sehingga hipotesis yang diambil adalah Ho ditolak dan $\mathrm{H}_{1}$ diterima.

4. Diperoleh Koefisien Determinasi $\left(\mathrm{R}^{2}\right)$ sebesar 0,780, artinya bahwa $78 \%$ keragaman perolehan jumlah mahasiswa perguruan tinggi ISTA disebabkan oleh keragaman kualitas pendidikan dalam proses belajar mengajar dan Promosi yang dilakukan kepada masyarakat, sedangkan sisanya 22\% disebabkan oleh faktor lainnya yang dalam penelitian ini tidak dianalisis lebih lanjut. 


\section{DAFTAR PUSTAKA}

Ansor SA dan Muttahidah. (2016). Pengantar Manajemen. Yogyakarta: Fajar Media Press.

Badrudin. (2013). Dasar-dasar Manajemen. Bandung: Alfabeta.

Colquitt, J. A., Lepine, J. A., dan Wesson, M. J. (2011). Organizational Behavior Improving Performance and Commitment in Workplace.New York: McGraw Hill

Crosby, P.B. (1979). Quality is Free The Art of Making Quality Certain. Mc.Graw Hill Book Company

Daft, RL. (2010). Era baru Manajemen. Jakarta: Salemba empat,

Depdiknas. (2009). Undang-Undang Sistem Pendidikan Nasional, Jakarta: Bina Aksara

Deming, E.W. (1992). Out of Crisis, Massachusetts Institute of Tech. Cambridge: Mass.

Deigenbaum, A.V. (1983). Total Quality Control. New York: Mc Graw Hill Book Co.

Drucker, P. (1999). Management Chalanges for 21th century. New York: Harper Collins Publishers.

Edward Salis. (2008). Total Quality Management in Education, Manajemen Mutu Pendidikan. Yogyakarta: IRCiSoD.

Handoko, HT. (2000). Dasar-dasar Manajemen Produksi dan Operasi. Yogyakarta: BPFE

Heizer, Jay and Render, B. (1996). Production and Operation Management Strategic and Tactical Decisions. New Jersey: Prentice Hall.

Kotler, Philip. (1997). Manajemen Pemasaran. Jakarta: Prenhallindo.

Mukherje S and Basu SK. (2005). Oragnization, Management and Business Communication. New Delhi, New Age Intl.

Purwanto. (2006). Manajemen Strategi. Bandung: Yrama Widya

Rao, Thukaram. (2009). Office Organization and Management. New Delhi: SP Abora.

Riduan dan Engkos Ahmad Kuncoro. (2007). Cara Menggunakan dan Memakai Analisis Jalur. Bandung: Alfabeta

Rowley, Jennifer. (1995). A New Lecturer's Simple Guide To Quality Issues In Higher Education. International Journal of Education Management.

Russel R, and Taylor. (1995). Production and Operation Management Focusing on Quality and Competitiveness. New Jersey: Prentice Hall

Sconberger, JR and Knod, ME. (1997). Operation Management Custumer Focused Principle. Chicago: IRwin

Singarimbun, Masri \& Effendi, Sofian. (2009). Metode Penelitian Survei. Jakarta: LP3ES.

Sudjana. (2000). Metode Statistika. Bandung: Tarsito

Sugiyono. (2004). Metode Penelitian Administrasi. Bandung: Alfabeta. 
Stamatis, D H. (1996). Total Quality Service. St: Lucia Press USA.

Usman, Husaini. (2009). Manajemen, teori, praktek dan riset Pendidikan. Jakarta: Bumi Aksara. 